\title{
Association of IREB2 and CHRNA3 polymorphisms with airflow obstruction in severe alpha-1 antitrypsin deficiency
}

\author{
Woo Jin Kim ${ }^{1}$, Alice M Wood ${ }^{2}$, Alan F Barker ${ }^{3}$, Mark L Brantly ${ }^{4}$, Edward J Campbell ${ }^{5}$, Edward Eden ${ }^{6}$, \\ Gerard McElvaney ${ }^{7}$, Stephen I Rennard ${ }^{8}$, Robert A Sandhaus ${ }^{9}$, James M Stocks ${ }^{10}$, James K Stoller ${ }^{11}$, \\ Charlie Strange ${ }^{12}$, Gerard Turino ${ }^{13}$, Edwin K Silverman ${ }^{14}$, Robert A Stockley ${ }^{15}$ and Dawn L DeMeo ${ }^{14^{*}}$
}

\begin{abstract}
Background: The development of COPD in subjects with alpha-1 antitrypsin (AAT) deficiency is likely to be influenced by modifier genes. Genome-wide association studies and integrative genomics approaches in COPD have demonstrated significant associations with SNPs in the chromosome $15 q$ region that includes CHRNA3 (cholinergic nicotine receptor alpha3) and IREB2 (iron regulatory binding protein 2).

We investigated whether SNPs in the chromosome 15q region would be modifiers for lung function and COPD in AAT deficiency.

Methods: The current analysis included 378 PIZZ subjects in the AAT Genetic Modifiers Study and a replication cohort of 458 subjects from the UK AAT Deficiency National Registry. Nine SNPs in LOC123688, CHRNA3 and IREB2 were selected for genotyping. $\mathrm{FEV}_{1}$ percent of predicted and $\mathrm{FEV}_{1} / \mathrm{FVC}$ ratio were analyzed as quantitative phenotypes. Family-based association analysis was performed in the AAT Genetic Modifiers Study. In the replication set, general linear models were used for quantitative phenotypes and logistic regression models were used for the presence/absence of emphysema or COPD.

Results: Three SNPs (rs2568494 in IREB2, rs8034191 in LOC123688, and rs1051730 in CHRNA3) were associated with pre-bronchodilator FEV 1 percent of predicted in the AAT Genetic Modifiers Study. Two SNPs (rs2568494 and rs 1051730) were associated with the post-bronchodilator $\mathrm{FEV}_{1}$ percent of predicted and pre-bronchodilator $\mathrm{FEV}_{1} / \mathrm{FVC}$ ratio; SNP-by-gender interactions were observed. In the UK National Registry dataset, rs2568494 was significantly associated with emphysema in the male subgroup; significant SNP-by-smoking interactions were observed.
\end{abstract}

Conclusions: IREB2 and CHRNA3 are potential genetic modifiers of COPD phenotypes in individuals with severe AAT deficiency and may be sex-specific in their impact.

Keywords: CHRNA3, Chronic obstructive pulmonary disease, Genetic association analysis, Genetic modifiers, IREB2

\section{Background}

Chronic obstructive pulmonary disease (COPD) is a complex disease characterized by persistent airflow limitation. COPD risk likely results from the cumulative effect of environmental factors (especially cigarette smoking), genetic factors, and gene-by-environment

\footnotetext{
* Correspondence: dawn.demeo@channing.harvard.edu

${ }^{14}$ Channing Laboratory and the Division of Pulmonary and Critical Care Medicine, Brigham and Women's Hospital, and Harvard Medical School, Boston, MA, USA

Full list of author information is available at the end of the article
}

interactions [1]. Alpha-1 antitrypsin (AAT) deficiency, typically caused by homozygosity for the $\mathrm{Z}$ allele at the AAT gene (SERPINA1), is a proven genetic cause of COPD. However, the development of COPD and emphysema in subjects with AAT deficiency is highly variable and is likely influenced by modifier genes and environmental factors [2-4].

Spirometric measurements of pulmonary function are widely used phenotypes in evaluating AAT deficient subjects and monitoring lung function decline [5]; CT scan assessments for emphysema have been used as

\section{Biomed Central}

(c) 2012 Kim et al; licensee BioMed Central Ltd. This is an Open Access article distributed under the terms of the Creative Commons Attribution License (http://creativecommons.org/licenses/by/2.0), which permits unrestricted use, distribution, and reproduction in any medium, provided the original work is properly cited. 
additional intermediate phenotypes of COPD to overcome some of the heterogeneity inherent in spirometric classifications alone. Familial aggregation studies of pulmonary function have suggested additional modifier genes in AAT deficiency subjects [6,7]. A few potential AAT candidate modifier genes, including NOS3 [8], GSTP1 [9], TNF [10], and IL10 [11], have been reported so far, but these results have not been consistently replicated.

Genome-wide association (GWA) studies have revolutionized the identification of susceptibility genes for complex diseases. Three recent GWA studies showed that SNPs in a region of chromosome 15q25 were significantly associated with lung cancer; several nicotinic acetylcholine receptor genes, including CHRNA3 and LOC123688, are located in this region [12-14]. A genome-wide association (GWA) study in COPD also showed significant associations between COPD susceptibility and SNPs in this region [15]. This region was also associated with airflow obstruction and emphysema $[16,17]$. Interestingly, in addition to nicotinic acetylcholine receptor genes, this region also includes IREB2 (iron regulatory binding protein 2). IREB2 was identified as a potential COPD susceptibility gene using an integrative genomics approach with gene expression analysis of lung tissue samples followed by genetic association analysis [18]. We hypothesized that SNPs in this chromosome $15 q$ region may be modifiers of intermediate phenotypes of COPD in subjects with severe AAT deficiency.

\section{Methods \\ Study subjects}

The current analysis included 378 subjects with severe AAT deficiency (protease inhibitor [PI] ZZ) from 167 families in the AAT Genetic Modifiers Study. Ascertainment of eligible sibling pairs was based on homozygosity for the $\mathrm{Z}$ allele at the SERPINA1 locus as previously described [19]. Pre- and post-bronchodilator study spirometry testing was performed according to American Thoracic Society (ATS) standards as described previously [19]. Percent predicted values for $\mathrm{FEV}_{1}$ were calculated using equations of Crapo and colleagues for Caucasian subjects [20]. The $\mathrm{FEV}_{1} / \mathrm{FVC}$ ratio was analyzed using unadjusted values. Pack-years of cigarette smoking were calculated by multiplying the number of years smoked by the average number of daily cigarettes smoked, divided by 20. All participants provided written informed consent, and the study protocol was approved by individual Institutional Review Boards at each of the participating clinical centers (Partners IRB, 2001P001237). 458 unrelated Caucasian subjects from the UK AATD National Registry were also genotyped. Approval for the study was given by the local ethics committee. All patients had a serum alpha- 1 antitrypsin (AAT) level of $<11 \mu \mathrm{M}$ and PI
ZZ genotype confirmed by allele-specific PCR (Heredilab, Salt Lake City, Utah, USA). None of the UK subjects had ever received AAT augmentation therapy. A full clinical assessment including smoke exposure, presence of chronic bronchitis (defined as a productive cough for at least 3 months in at least 2 consecutive years [21]), lung function testing and high resolution CT scanning of the chest was undertaken, as described previously [22]. The presence of emphysema was determined by the appearance of the scan and density mask analysis of slices at the level of the aortic arch (representing the upper zone) and the inferior pulmonary vein (representing the lower zone) using a threshold of -910 Hounsfield Units (HU). This HU threshold has been validated against physiological measures in AATD [22]. Patients whose voxel index exceeded values seen in normal subjects in either zone [23] were classified as having emphysema.

\section{Genotyping}

Two SNPs (rs8034191 and rs1051730) in chromosome 15 were selected from the previous GWA in COPD [15]. Additionally, 7 SNPs in IREB2 were selected using pairwise linkage disequilibrium (LD)-tagging in Tagger with a minimum minor allele frequency of 0.05 and $\mathrm{r}^{2}$ threshold of 0.8 [24]. SNPs were genotyped using Sequenom (San Diego, CA) assays in the AAT Genetic Modifiers Study. All family data were evaluated for familial inconsistencies using the PEDCHECK program [25].

In UK AATD National Registry study, genotyping was carried out using TaqMan ${ }^{\circledR}$ technologies (Applied Biosystems, UK) on an ABI7900 HT for 3 SNPs associated in the test dataset (rs2568494, IREB2; rs8034191, LOC123688; rs1051730, CHRNA3). All genotyping assays were pre-validated by the suppliers, and all plates included appropriate negative controls.

\section{Statistical analysis}

Hardy-Weinberg equilibrium was assessed using goodness of fit tests. Pre- and post-bronchodilator $\mathrm{FEV}_{1}$ percent of predicted and pre- and post-bronchodilator $\mathrm{FEV}_{1} / \mathrm{FVC}$ ratio were analyzed as quantitative phenotypes. Family-based association analysis was performed using PBAT software version 3.6 [26] assuming additive genetic models, adjusting for pack-years and pack-years ${ }^{2}$ of cigarette smoking, under the null hypothesis of no linkage and no association in the AAT Genetic Modifiers Study. In addition to the overall model, we evaluated gender-stratified models and models that included a SNP-by-smoking or a SNP-by-gender interaction term. Haplotype analysis was performed using 8, 4, 3, 2 SNP adjacent sliding windows in PBAT.

In the UK AATD National Registry study, data were analyzed using SPSS (version 16, Chicago: SPSS Inc). Quantitative genetic association analysis was carried out 
for $\mathrm{FEV}_{1}$ and $\mathrm{FEV}_{1} / \mathrm{FVC}$ using general linear models, adjusting for age, gender and smoke exposure (as packyears and pack-years ${ }^{2}$ ). Logistic regression models were used for the presence of emphysema or COPD (defined as post bronchodilator $\mathrm{FEV}_{1} / \mathrm{FVC}<0.7$ ) accounting for covariates as before. Additive models were assumed for all SNPs. Gender stratification and SNP-by-gender and SNP-by-smoking interaction analyses were also carried out, as in the test dataset.

\section{Results}

\section{Demographic characteristics}

The mean age of subjects was 52.2 years, and mean postbronchodilator $\mathrm{FEV}_{1}$ was $65.9 \%$ predicted in the AAT Genetic Modifiers Study and 50.3 years and $53.8 \%$ predicted in the UK AATD National Registry, respectively (Table 1). Male subjects were $46 \%$ in AAT Genetic Modifiers Study and 59\% in UK AATD National Registry, respectively. Three hundred and sixty-six subjects (79.8\%) had emphysema in UK AATD National Registry.

\section{Association analysis}

There were no deviations from Hardy Weinberg equilibrium for any of the genotyped SNPs.

In the AAT Genetic Modifiers Study, three SNPs (rs2568494 in IREB2, rs8034191 in LOC123688, and rs1051730 in CHRNA3) were associated with pre-bronchodilator $\mathrm{FEV}_{1}$ percent of predicted ( $p<0.05$ Table 2 Figure 1). Two SNPs (rs2568494 and rs1051730) were associated with post-bronchodilator $\mathrm{FEV}_{1}$ percent of predicted and pre-bronchodilator $\mathrm{FEV}_{1} / \mathrm{FVC}$ ratio. One SNP (rs1051730) was associated with post-bronchodilator $\mathrm{FEV}_{1} / \mathrm{FVC}$ ratio (Table 2). Linkage disequilibrium (assessed with $\mathrm{r}^{2}$ ) between rs8034191 and the 1051730 was 0.9 (Figure 2). There was significant association only with a 2 SNP haplotype including rs8034191 and rs1051730 with pre- bronchodilator $\mathrm{FEV}_{1} / \mathrm{FVC}$ ratio (global test statistic; $p=0.05$ ) using PBAT.

\section{Interactions with cigarette smoking}

There was no association between any of the genotyped SNPs and pack-years of smoking as the outcome in the
AAT Genetic Modifiers Study. Inclusion of a SNP-bypack-years interaction term for the lung function phenotypes showed significant interaction of rs1051730 with pack-years of smoking for the pre- bronchodilator $\mathrm{FEV}_{1} / \mathrm{FVC}$ ratio (main effect; $p=0.02$, interaction effect; $p=0.04)$. There was no significant association with lung function phenotypes when the study population was stratified into groups of ever-smokers $(n=233)$ and never-smokers $(n=145)$ although this stratified analysis reduced the number of informative families considerably.

\section{Genotype-by-gender interactions and gender stratification}

SNP-by-gender interaction analysis showed significant interaction of rs2568494, rs8034191, and rs1051730 with gender in models for the post-bronchodilator $\mathrm{FEV}_{1} / \mathrm{FVC}$ ratio (main effect; $p=0.04,0.04,0.02$, interaction effect; $p=0.02,0.008,0.004$, respectively). Additionally, rs1051730 showed significant interaction in models for pre and post-bronchodilator $\mathrm{FEV}_{1}$ and pre-bronchodilator $\mathrm{FEV}_{1} / \mathrm{FVC}$ ratio (main effect; $p=0.04,0.04,0.08$, interaction effect; $p=0.04,0.02,0.04$, respectively).

In the stratified analysis, for the male subgroup, the $p$ values were similar to the whole cohort results, with rs8034191 showing significant association with pre- and post-bronchodilator $\mathrm{FEV}_{1}$ percent of predicted and post-bronchodilator $\mathrm{FEV}_{1} / \mathrm{FVC}$ ratio (Table 3). However, in the female subgroup, there was no significant association with lung function phenotypes.

\section{Replication analysis}

In the initial analyses in the whole UK dataset, no significant associations with quantitative phenotypes including $\mathrm{FEV}_{1}$ and $\mathrm{FEV}_{1} / \mathrm{FVC}$ and qualitative presence of emphysema and COPD were observed (all $p>0.05$ ). Gender interaction was apparent for rs2568494 with both COPD and emphysema (main effect $p=0.10$, interaction $p=0.04$ and $0.06,0.03$ respectively). No other statistically significant gender interactions were observed. In the sex-stratified models, evidence of association for SNPs in IREB2 and LOC123688 was observed. A trend

Table 1 Baseline characteristics for PI ZZ individuals in the AAT Genetic Modifiers Study and the UK AATD National Registry

\begin{tabular}{lll}
\hline Characteristics & $\begin{array}{l}\text { AAT Genetic Modifiers Study } \\
(\boldsymbol{n}=\mathbf{3 7 8})\end{array}$ & $\begin{array}{l}\text { UK national registry for AATD } \\
(\boldsymbol{n}=\mathbf{4 5 8 )}\end{array}$ \\
\hline Age, years & $52.2 \pm 9.7$ & $50.3 \pm 10.4$ \\
Male sex (\%) & $173(46 \%)$ & $252(55 \%)$ \\
FEV $\%$ predicted & $65.9 \pm 33.5$ & $53.8 \pm 32.2$ \\
FEV 1 FVC & $0.551 \pm 0.207$ & $0.445 \pm 0.194$ \\
Pack-years for ever smokers & $18.2 \pm 14.5$ & $15.9 \pm 14.7$ \\
\hline
\end{tabular}

Data are presented as means ( \pm S.D.) in the AAT Genetic Modifiers Study and the UK national registry for AATD, unless otherwise noted 
Table 2 Genetic association results between SNPs in chromosome 15 and lung function in the AAT Genetic Modifiers Study

\begin{tabular}{|c|c|c|c|c|c|c|c|}
\hline \multicolumn{8}{|c|}{$P$-Values for Different Phenotypes } \\
\hline Gene & SNP & & MAF & $\begin{array}{l}\text { pre-FEV }{ }_{1} \% \\
\text { predicted }\end{array}$ & $\begin{array}{l}\text { post-FEV } 1 \% \\
\text { predicted }\end{array}$ & $\begin{array}{l}\text { pre- } \\
\text { FEV }_{1} / \mathrm{FVC}\end{array}$ & $\begin{array}{l}\text { post- } \\
\mathrm{FEV}_{1} / \mathrm{FVC}\end{array}$ \\
\hline \multirow[t]{7}{*}{ IREB2 } & rs2568494 & intron & 0.30 & $0.02^{*}$ & $0.03^{*}$ & $0.05^{*}$ & 0.06 \\
\hline & rs2656069 & intron & 0.22 & 0.48 & 0.29 & 0.59 & 0.46 \\
\hline & rs1964678 & intron & 0.43 & 0.75 & 0.91 & 0.58 & 0.83 \\
\hline & rs12593229 & intron & 0.43 & 0.82 & 0.79 & 0.64 & 0.93 \\
\hline & rs10851906 & intron & 0.23 & 0.29 & 0.17 & 0.41 & 0.31 \\
\hline & rs965604 & intron & 0.43 & 0.76 & 0.99 & 0.54 & 0.65 \\
\hline & rs13180 & exon & 0.43 & 0.69 & 0.96 & 0.53 & 0.79 \\
\hline LOC123688 & rs8034191 & intron & 0.29 & $0.04^{*}$ & 0.07 & 0.09 & 0.14 \\
\hline CHRNA3 & rs1051730 & exon & 0.31 & $0.02^{*}$ & $0.03^{*}$ & $0.03^{*}$ & $0.05^{*}$ \\
\hline
\end{tabular}

$\mathrm{MAF}=$ minor allele frequency

Each model was analyzed assuming an additive mode of inheritance adjusting for pack-years and pack-years ${ }^{2}$

${ }^{*} p \leq 0.05$

was observed for association of rs8034191 and rs2568494 with COPD in the male subgroup, the risk alleles being $C$ and A respectively (both $p=0.09$ ). The SNP rs2568494 in IREB2 was significantly associated with emphysema in the male subgroup, the A allele conferring an odds ratio and 95\% confidence interval (OR and $95 \% \mathrm{CI})$ of disease of $2.67(1.10-6.51, p=0.03)$. No association was seen with rs1051730 with emphysema.

With addition of a SNP-by-smoking interaction term, both rs8034191 and rs2568494 were associated with COPD in the male subgroup (main effect, $p=0.03$; interaction effect, $p=0.02$; and main effect, $p=0.04$; interaction effect, $p=0.003$, respectively). Similar associations with emphysema were seen for rs2568494 ( $p=$ 0.03 and 0.02 respectively). Positive findings in the two datasets are summarized in Table 4.

\section{Discussion}

SNPs in the chromosome 15 CHRNA3/CHRNA5/ LOC123688/IREB2 region have been shown to have

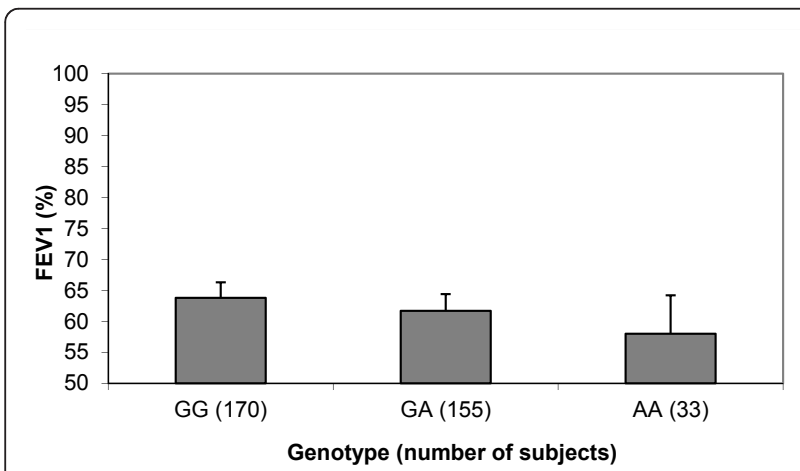

Figure $1 \mathrm{FEV}_{1}$ by CHRNA3 genotype (rs1051730) in the AAT Genetic Modifiers Study cohort. Mean values (+ SEM) for a percent of predicted $\mathrm{FEV}_{1}$ are shown ( $p$ value $=0.02$ ). associations with lung cancer and COPD unrelated to AAT deficiency. In our current analysis, SNPs in IREB2, LOC123688 and CHRNA3 genes were shown to be associated with lung function phenotypes in AAT deficient subjects (all PI ZZ) from the AAT Genetic Modifiers Study, and suggested a potential sex-specific effect. Replication in another cohort of AAT deficient subjects from the UK showed that a SNP in IREB2 was also associated with emphysema in men. This suggests that chromosome 15q region genes that were found by GWA studies and gene expression analysis of lung tissue samples may also be modifier genes of COPD and emphysema in AAT deficient subjects.

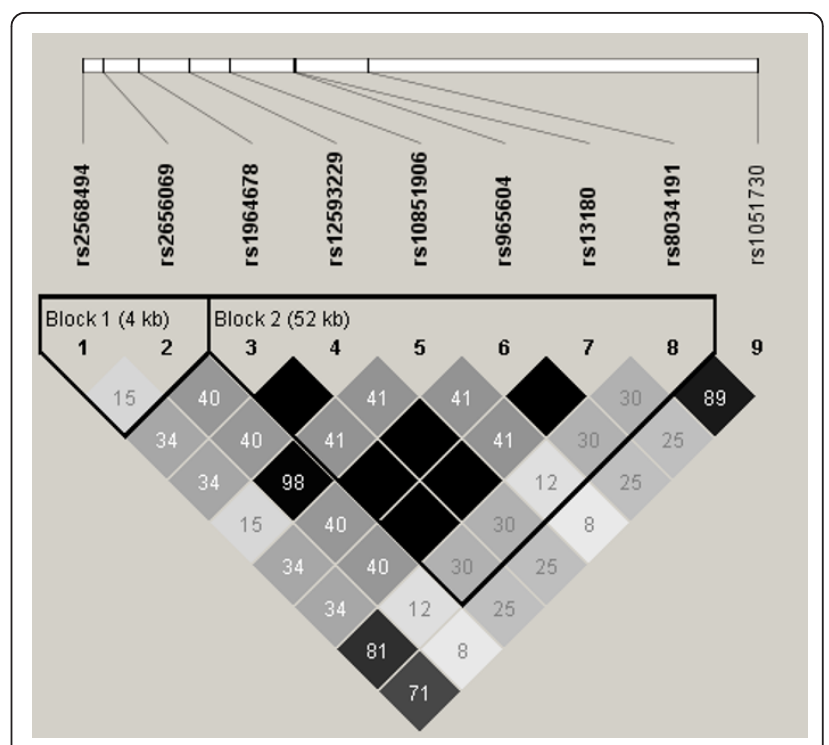

Figure 2 Linkage disequilibrium (LD) among SNPs analyzed in chromosome 15. LD values are presented as $r^{2}$. 
Table 3 Genetic association results between SNPs in chromosome 15 and lung function of male subgroup in the AAT Genetic Modifiers Study cohort

\begin{tabular}{|c|c|c|c|c|c|c|}
\hline \multicolumn{7}{|c|}{$P$-Values for Different Phenotypes } \\
\hline Gene & SNP & & pre-FEV ${ }_{1} \%$ predicted & post-FEV ${ }_{1} \%$ predicted & $\begin{array}{l}\text { pre- } \\
\text { FEV }_{1} / \mathrm{FVC}\end{array}$ & $\begin{array}{l}\text { post- } \\
\text { FEV }_{1} / \mathrm{FVC}\end{array}$ \\
\hline \multirow{7}{*}{ IREB2 } & rs2568494 & intron & $0.03^{*}$ & $0.04^{*}$ & 0.07 & $0.03^{*}$ \\
\hline & rs2656069 & intron & 0.97 & 0.87 & 0.64 & 0.65 \\
\hline & rs1964678 & intron & 0.99 & 0.96 & 0.85 & 0.78 \\
\hline & rs12593229 & intron & 0.95 & 0.93 & 0.87 & 0.76 \\
\hline & rs10851906 & intron & 0.70 & 0.61 & 0.84 & 0.80 \\
\hline & rs965604 & intron & 0.84 & 0.90 & 0.75 & 0.70 \\
\hline & rs13180 & exon & 0.85 & 0.91 & 0.76 & 0.71 \\
\hline LOC123688 & rs8034191 & intron & $0.04^{*}$ & $0.04^{*}$ & 0.12 & $0.04^{*}$ \\
\hline CHRNA3 & rs1051730 & exon & $0.02^{*}$ & $0.02^{*}$ & 0.07 & $0.02^{*}$ \\
\hline
\end{tabular}

Each model was analyzed assuming an additive mode of inheritance adjusting for pack-years and pack-years ${ }^{2}$

* $p \leq 0.05$

CHRNA3 was associated with lung cancer in three separate large GWA studies. This gene was associated with COPD by GWA and the association was replicated in two other COPD cohorts. There have also been recent reports of an association with smoking addiction [27], so it is unclear whether the lung cancer and COPD associations relate to smoking behavior, another aspect of lung biology, or both. CHRNA3 is a subunit gene of the nicotinic cholinergic receptor and expressed in autonomic ganglia and brain but is also expressed in bronchial and non-bronchial epithelial cells [28]. Expression in lung cancer cells and signal transduction and apoptosis studies suggests a potential role in carcinogenesis [29]. Interestingly, there are not many observations of lung cancer in patients with AAT deficiency, perhaps because of mortality associated with the development of severe COPD at an early age. Whether there is a common mechanism unrelated to smoking in the pathogenesis of lung cancer and COPD, or whether these

Table 4 Positive findings of genetic association analysis in the AAT Genetic Modifiers Study and the UK AATD National Registry

\begin{tabular}{|c|c|c|}
\hline & $\begin{array}{l}\text { AAT Genetic Modifiers } \\
\text { Study }\end{array}$ & $\begin{array}{l}\text { UK AATD National } \\
\text { Registry }\end{array}$ \\
\hline All subjects & $\begin{array}{l}\text { Association with pre- and } \\
\text { post- } \mathrm{FEV}_{1} \% \text { predicted and } \\
\text { pre- and post- } \mathrm{FEV}_{1} / \mathrm{FVC}\end{array}$ & none \\
\hline $\begin{array}{l}\text { Interaction } \\
\text { with } \\
\text { gender }\end{array}$ & yes & yes \\
\hline $\begin{array}{l}\text { Interaction } \\
\text { with } \\
\text { smoking }\end{array}$ & yes & only in the male subgroup \\
\hline $\begin{array}{l}\text { Male } \\
\text { subgroup }\end{array}$ & $\begin{array}{l}\text { association with } \mathrm{FEV}_{1} \text { and } \\
\mathrm{FEV}_{1} / \mathrm{FVC}\end{array}$ & $\begin{array}{l}\text { association with } \\
\text { emphysema } \\
\text { association with COPD } \\
\text { after adding smoking } \\
\text { interaction term }\end{array}$ \\
\hline
\end{tabular}

previously reported associations relate to smoking addiction is unclear.

IREB2 is a protein of iron-responsive elements (IREs) and is regulated in response to iron and oxygen supply [30]. IREB2-/- mice have aberrant iron homeostasis and accumulate iron in the intestine and the central nervous system(CNS); the CNS accumulation may lead to neurodegenerative disease [31]. Excess iron can be toxic, but the mechanism of neurodegenerative disease is unclear; work is in progress to further characterize the functional pathways impacted by IREB2 in the lung. IREB2 was found to be differentially expressed according to lung function by microarray experiments, and the SNPs in IREB2 showed associations in both a COPD case-control study and family-based studies including the Boston Early-onset COPD and International COPD Genetics Network studies [18]. In a recent report, IREB2 polymorphisms were associated with COPD susceptibility in a European population [32]. Interestingly, rs2568494 was significantly associated with COPD in three studies including our current study.

Previous studies of AAT deficient subjects showed that lung function was lower in men than women [33], and previous analyses in the AAT Genetic Modifiers Study also showed lower lung function in men [19]. Our current study suggests that genetic modifier effects of IREB2 and CHRNA3 may be more prominent in malespotentially contributing to some of the sex-specific features of COPD susceptibility and severity among PI ZZ subjects, although a larger sample size is needed to verify a gene-by-sex interaction.

In this study, there was no association between IREB2 and CHRNA3 genes and smoking intensity. In the AAT Genetic Modifiers Study, results showed no association when the cohort was stratified by smoking history (ever smokers versus never smokers). However, there was a marginal interaction of rs1051730 with smoking. In the 
UK study, there were significant smoking interactions of rs2568494 and rs8034191. Smoking markedly increases the risk of COPD and lowers the age-of-onset of COPD in AAT deficient subjects $[6,19]$, and despite small sample sizes, we found reasonable evidence for gene-bysmoking interactions in the chromosome $15 \mathrm{q}$ region.

There are several limitations in this study. Multiple statistical comparisons are a potential concern in any complex disease genetics study. Adjusting for either 3 genes or 9 SNPs tested, a $p$ value of 0.02 is marginal. Additionally, the association with pulmonary function did not replicate in the UK population, potentially due to phenotypic heterogeneity between the two cohorts. Specifically, the UK subjects have lower mean FEV1 and potentially more emphysema, both of which could influence non-replication. Of note, the association with emphysema was investigated only in the UK population as chest CT scan data collection was not part of the AAT Genetic Modifiers Study. Considering that these SNPs (rs2568494 in IREB2, rs8034191 in LOC123688, and rs1051730 in CHRNA3) were associated with intermediate phenotypes of COPD in other populations and that we include an independent AAT deficient replication cohort, our result are likely meaningful. Additionally, this test- replication approach is even more appealing since all subjects were homozygous recessive for the AAT risk locus (PI ZZ). Also, replication of our results showed association with emphysema, a less heterogeneous pulmonary phenotype. The associated SNPs included two intronic (rs2568494, rs8034191) and one synonymous exonic (rs1051730) SNP. The exonic SNP was not associated with COPD-related phenotypes in the UK cohort. Another limitation of our current study is that rare functional variants in this chromosome 15 region may be contributing to the role of these genes in COPD; genome sequencing efforts in AAT deficient cohorts would be valuable to study rare variant associations. Functional data for associated variants are currently lacking, but many groups are pursuing functional work on this chromosome 15 region.

\section{Conclusion}

We have identified that the chromosome 15 q25 region likely contains at least one potential modifier gene of COPD phenotypes in individuals with severe AAT deficiency. The association may be due to smoking behavior, but this is less likely; additionally, these associations may have sex-specific effects. Future directions will include further evaluation of the gene-by-sex interaction in larger cohort with AAT deficiency and identification of the functional variant or variants in this region.

\section{Abbreviations}

AAT: Alpha-1 antitrypsin; CHRNA3: Cholinergic nicotine receptor alpha3; GWA: Genome-wide association; IREB2: Iron regulatory binding protein 2; MAF: Minor allele frequency

\section{Acknowledgements}

This work was supported by US National Institutes of Health [Grant R01 HL68926, R01 HL075478, R01 HL084323, P01 HL083069 (EKS) and HL089438]. The UK AATD Registry was supported by an unrestricted grant by Talecris as part of the ADAPT program. Additionally, DLD is supported by a Clinician Scientist Development Award from the Doris Duke Foundation.

\section{Author details}

'Department of Internal Medicine, Kangwon National University, Chuncheon, South Korea. ${ }^{2}$ School of Clinical and Experimental Medicine, University of Birmingham, Birmingham, UK. ${ }^{3}$ Oregon Health and Science University, Portland, OR, USA. ${ }^{4}$ University of Florida, Gainesville, FL, USA. ${ }^{5}$ Intermountain Health Care, Provo, and Heredilab, Inc, Salt Lake City, UT, USA. 'St. Luke's/ Roosevelt Hospital, New York, NY, USA. ${ }^{7}$ Beaumont Hospital, Dublin, Ireland. ${ }^{8}$ University of Nebraska, Omaha, NE, USA. ${ }^{9}$ National Jewish Health, Denver, CO, USA. ${ }^{10}$ University of Texas at Tyler, Tyler, TX, USA. ${ }^{11}$ Cleveland Clinic, Cleveland, OH, USA. ${ }^{12}$ Medical University of South Carolina, Charleston, SC, USA. ${ }^{13}$ St. Luke's/Roosevelt Hospital, New York, NY, USA. ${ }^{14}$ Channing Laboratory and the Division of Pulmonary and Critical Care Medicine, Brigham and Women's Hospital, and Harvard Medical School, Boston, MA, USA. ${ }^{15}$ Lung Investigation Unit, University Hospitals Birmingham, Birmingham, UK.

\section{Authors' contributions}

All authors contributed to the study design, data collection and analysis, and writing of the manuscript. WJK, AMW, DLD contributed to data analysis. All authors read and approved the final manuscript.

\section{Competing interests}

WJK, AMW, AFB, MLB, EJC, EE, GM, RAS and GT have reported that no potential conflicts of interest. SIR was supported from GlaxoSmithKline for travel to meetings for the study. JMS received grant support from Talecris, Baxter. JKS received grant support from AstraZeneca, and honoraria from Talecris, Baxter, CSL Behring, Boehringer Ingelheim, Kamada, Grifols, and has received fees for participation in review activities from Shire and AsthmaTx. CS received consulting fees from AstraZeneca, Talecris, Baxter, Forest, Phamaceuticals, Uptake Medical, Pulmonx and payment for lectures from Talecris and AstraZeneca. EKS received grant support and consulting fees from GlaxoSmithKline for studies of COPD genetics and honoraria and consulting fees from AstraZeneca. RAS received grant support, honoraria and consulting fees and supported for travel to meetings for the study from Talecris. DLD received grant support from Doris Duke Charitable Foundation.

Received: 11 December 2011 Accepted: 22 February 2012 Published: 22 February 2012

\section{References}

1. Rabe KF, Hurd S, Anzueto A, Barnes PJ, Buist SA, Calverley P, Fukuchi Y, Jenkins C, Rodriguez-Roisin R, van Weel C, Zielinski J: Global Initiative for Chronic Obstructive Lung Disease. Global strategy for the diagnosis, management, and prevention of chronic obstructive pulmonary disease: Gold executive summary. Am J Respir Crit Care Med 2007, 176:532-555.

2. DeMeo DL, Silverman EK: Alpha1-antitrypsin deficiency. 2: Genetic aspects of alpha-1-antitrypsin deficiency: Phenotypes and genetic modifiers of emphysema risk. Thorax 2004, 59:259-264.

3. Wood AM, Needham M, Simmonds MJ, Newby PR, Gough SC, Stockley RA: Phenotype differences in alpha-1-deficient sibling pairs may relate to genetic variation. COPD 2008, 5:353-359.

4. Wood AM, Harrison RM, Semple S, Ayres JG, Stockley RA: Outdoor air pollution is associated with rapid decline of lung function in alpha-1antitrypsin deficiency. Occup Environ Med 2010, 67:556-561.

5. American Thoracic Society/European Respiratory Society statement: Standards for the diagnosis and management of individuals with alpha1 antitrypsin deficiency. Am J Respir Crit Care Med 2003, 168:818-900. 
6. Silverman EK, Province MA, Rao DC, Pierce JA, Campbell EJ: A family study of the variability of pulmonary function in alpha 1-antitrypsin deficiency. Quantitative phenotypes. Am Rev Respir Dis 1990, 142:1015-1021.

7. DeMeo DL, Campbell EJ, Brantly ML, Barker AF, Eden E, McElvaney NG, Rennard SI, Stocks JM, Stoller JK, Strange C, Turino G, Sandhaus RA, Silverman EK: Heritability of lung function in severe alpha-1 antitrypsin deficiency. Hum Hered 2009, 67:38-45.

8. Novoradovsky A, Brantly ML, Waclawiw MA, Chaudhary PP, Ihara H, Qi L, Eissa NT, Barnes PM, Gabriele KM, Ehrmantraut ME, Rogliani P, Moss J: Endothelial nitric oxide synthase as a potential susceptibility gene in the pathogenesis of emphysema in alpha 1-antitrypsin deficiency. Am J Respir Cell Mol Biol 1999, 20:441-447.

9. Rodriguez F, de la Roza C, Jardi R, Schaper M, Vidal R, Miravitlles M: Glutathione s-transferase $\mathrm{p} 1$ and lung function in patients with alpha1antitrypsin deficiency and COPD. Chest 2005, 127:1537-1543.

10. Wood AM, Simmonds MJ, Bayley DL, Newby PR, Gough SC, Stockley RA: The TNFalpha gene relates to clinical phenotype in alpha-1-antitrypsin deficiency. Respir Res 2008, 9:52.

11. DeMeo DL, Campbell EJ, Barker AF, Brantly ML, Eden E, McElvaney NG, Rennard SI, Sandhaus RA, Stocks JM, Stoller JK, Strange C, Turino G, Silverman EK: IL-10 polymorphisms are associated with airflow obstruction in severe alpha1-antitrypsin deficiency. Am J Respir Cell Mol Biol 2008, 38:114-120.

12. Thorgeirsson TE, Geller F, Sulem P, Rafnar T, Wiste A, Magnusson KP, Manolescu A, Thorleifaaon G, Stefansson H, Ingason A, Stacey SN, Bergthorsson JT, Thorlacius S, Gudmundsson J, Jonsson T, Jakobsdottir M, Saemundsdottir J, Olafsdottir O, Gudmendsson L, Bjornsdottir G, Kristjansson K, Skuladottir H, Isaksson HJ, Gudbjartsson T, Jones GT, Mueller T, Gottsater A, Flex A, Aben KK, de Vegt F, et al: A variant associated with nicotine dependence, lung cancer and peripheral arterial disease. Nature 2008, 452:638-642.

13. Hung RJ, McKay JD, Gaborieau V, Boffetta P, Hashibe M, Zaridze D, Mukeria A, Szeszenia-Dabrowska N, Lissowska J, Rudnai P, Fabianova E, Mates D, Bencko V, Foretova L, Janout V, Chen C, Goodman G, Field JK, Lilglou T, Xinarianos G, Cassidy A, McLaughlin J, Liu G, Narod S, Krokan HE, Skorpen F, Elvestad MB, Hveem K, Vatten L, Linseisen J: A susceptibility locus for lung cancer maps to nicotinic acetylcholine receptor subunit genes on 15q25. Nature 2008, 452:633-637.

14. Amos Cl, Wu X, Broderick P, Gorlov IP, Gu J, Eisen T, Dong Q, Zhang Q, Gu X, Vijayakrishnan J, Sullivan K, Matakidou A, Wang Y, Mills G, Doheny K, Tsai YY, Chen W, Shete S, Spitz MR, Houlston RS: Genome-wide association scan of tag SNPs identifies a susceptibility locus for lung cancer at 15q25.1. Nat Genet 2008, 40:616-622.

15. Pillai SG, Ge D, Zhu G, Kong X, Shianna KV, Need AC, Feng S, Hersh CP, Bakke P, Gulsvik A, Ruppert A, Lodrup Carlsen KC, Roses A, Anderson W, Rennard SI, Lomas DA, Silverman EK, Goldstein DB: ICGN Investigators. A genome-wide association study in chronic obstructive pulmonary disease (COPD): Identification of two major susceptibility loci. PLOS Genet 2009, 5:1000421

16. Pillai SG, Kong X, Edwards LD, Cho MH, Anderson WH, Coxson HO, Lomas DA, Silverman EK: ECLIPSE and ICGN Investigators. Loci identified by genome-wide association studies influence different disease-related phenotypes in chronic obstructive pulmonary disease. Am J Respir Crit Care Med 2010, 182:1498-1505.

17. Lambrechts D, Buysschaert I, Zanen P, Coolen J, Lays N, Cuppens H, Groen HJ, Dewever W, van Klaveren RJ, Verschakelen J, Wijmenga C, Postma DS, Decramer M, Janssens W: The 15q24/25 susceptibility variant for lung cancer and chronic obstructive pulmonary disease is associated with emphysema. Am J Respir Crit Care Med 2010, 181:486-493.

18. DeMeo DL, Mariani T, Bhattacharya S, Srisuma S, Lange C, Litonjua A, Bueno R, Pillai SG, Lomas DA, Sparrow D, Shapiro SD, Criner GJ, Kim HP, Chen Z, Choi AM, Reilly J, Silverman EK: Integration of genomic and genetic approached implicates IREB2 as a COPD susceptibility gene. Am J Hum Genet 2009, 85:493-502.

19. DeMeo DL, Sandhaus RA, Barker AF, Brantly ML, Eden E, McElvaney NG, Rennard S, Burchard E, Stocks JM, Stoller JK, Strange C, Turino GM, Campbell EJ, Silverman EK: Determinants of airflow obstruction in severe alpha-1-antitrypsin deficiency. Thorax 2007, 62:806-813.

20. Crapo RO MA, Gardener RM: Reference spirometric values using techniques and equipment that meet ats recommendations. Am Rev Respir Di 1982, 123:659-664.
21. Definition and classification of chronic bronchitis for clinical and epidemiological purposes. Lancet 1965, 285:775-779.

22. Dowson LJ, Guest PJ, Hill SL, Holder RL, Stockley RA: High-resolution computed tomography scanning in alpha1-antitrypsin deficiency: Relationship to lung function and health status. Eur Respir J 2001, 17:1097-1104.

23. Soejima K, Yamaguchi K, Kohda E, Takeshita K, Ito Y, Mastubara H, Oguma T, Inoue T, Okubo Y, Amakawa K, Tateno H, Shiomi T: Longitudinal follow-up study of smoking-induced lung density changes by high-resolution computed tomography. Am J Respir Crit Care Med 2000, 161:1264-1273.

24. de Bakker PI, Yelensky R, Pe'er I, Gabriel SB, Daly MJ, Altshuler D: Efficiency and power in genetic association studies. Nat Genet 2005, 37:1217-1223.

25. O'Connell JR, Weeks DE: Pedcheck: A program for identification of genotype incompatibilities in linkage analysis. Am J Hum Genet 1998, 63:259-266.

26. Lange C, DeMeo D, Silverman EK, Weiss ST, Laird NM: PBAT: tools for family-based association studies. Am J Hum Genet 2004, 74:367-369.

27. Saccone SF, Hinrichs AL, Saccone NL, Chase GA, Konvicka K, Madden PA Breslau N, Johnson EO, Hatsukami D, Pomerleau O, Swan GE, Goate AM, Rutter J, Bertelsen S, Fox L, Fugman D, Martin NG, Montgomery GW, Wang JC, Ballinger DG, Rice JP, Bierut LJ: Cholinergic nicotinic receptor genes implicated in a nicotine dependence association study targeting 348 candidate genes with 3713 SNPs. Hum Mol Genet 2007, 16:36-49.

28. Arredondo J, Chernyavsky Al, Marubio LM, Beaudet AL, Jolkovsky DL, Pinkerton KE, Grando SA: Receptor-mediated tobacco toxicity: Regulation of gene expression through alpha3beta2 nicotinic receptor in oral epithelial cells. Am J Pathol 2005, 166:597-613.

29. West KA, Brognard J, Clark AS, Linnoila IR, Yang X, Swain SM, Harris C, Belinsky S, Dennis PA: Rapid Akt activation by nicotine and a tobacco carcinogen modulates the phenotype of normal human airway epithelial cells. J Clin Invest 2003, 111:81-90.

30. Pantopoulos K: Iron metabolism and the ire/irp regulatory system: An update. Ann NY Acad Sci 2004, 1012:1-13.

31. LaVaute T, Smith S, Cooperman S, Iwai K, Land W, Meyron-Holtz E, Drake SK, Miller G, Abu-Asab M, Tsokos M, Switzer R, Grinberg A, Love P, Tresser N, Rouault TA: Targeted deletion of the gene encoding iron regulatory protein-2 causes misregulation of iron metabolism and neurodegenerative disease in mice. Nat Genet 2001, 27:209-214.

32. Chappell SL, Daly L, Lotya J, Alsaegh A, Guetta-Baranes T, Roca J, Rabinovich R, Morgan K, Millar AB, Donnelly SC, Keatings V, MacNee W, Stolk J, Hiemstra PS, Miniati M, Monti S, O'Connor CM, Kalsheker N: The role of IREB2 and transforming growth factor beta-1 genetic variants in COPD: a replication case-control study. BMC Med Genet 2011, 12:24.

33. Piitulainen E, Tornling G, Eriksson S: Effect of age and occupational exposure to airway irritants on lung function in non-smoking individuals with alpha 1-antitrypsin deficiency (PiZZ). Thorax 1997, 52:244-248.

doi:10.1186/1465-9921-13-16

Cite this article as: Kim et al:: Association of IREB2 and CHRNA3 polymorphisms with airflow obstruction in severe alpha-1 antitrypsin deficiency. Respiratory Research 2012 13:16.

\section{Submit your next manuscript to BioMed Central and take full advantage of:}

- Convenient online submission

- Thorough peer review

- No space constraints or color figure charges

- Immediate publication on acceptance

- Inclusion in PubMed, CAS, Scopus and Google Scholar

- Research which is freely available for redistribution

Submit your manuscript at www.biomedcentral.com/submit
C Biomed Central 